\begin{tabular}{|l|l|l|l|l|}
\hline Cuadernos de Investigación Geográfica & 2001 & $\mathbf{N}^{\circ} 27$ & pp. 27-38 & ISSN 0211-6820 \\
\hline
\end{tabular}

(C) Universidad de La Rioja

\title{
RAINFALL INTERCEPTION BY HOLM OAKS IN MEDITERRANEAN OPEN WOODLAND
}

BEATRIZMATEOS

SUSANASCHNABEL

Dpto. de Geografía, Universidad de Extremadura, Avda. de la Universidad, s/n, 10071 Cáceres, Spain

e-mail: abmateos@unex.es

ABSTRACT: The role of holm oaks (Quercus rotundifolia) in the redis tribution of precipitation was studied in the dehesas, a landuse system widespread in the southwestern part of the Iberian Peninsula. It consists of pastureland with an openly spaced tree cover. Measurements of through flow and stemflow were carried out in the Guadalperalon study catchment, and data of three hydrological years are available on an event basis. The effect of tree pruning on interception was also investigated, an activity carried out in intervals of approximately 10 years. Four trees were selec ted for monitoring, two non-pruned and two pruned individuals. Throughfall was measured with a total number of 163 raingauges distri buted in a regular grid below the tree canopies, and meteorological data was registered in intervals of 5 minutes. On average $26.8 \%$ of the annual rainfall is intercepted. The pruned trees intercept clearly less rainfall than the unpruned ones, with $23.6 \%$ and $29.9 \%$, respectively. Stemflow is of lit tle importance, representing less than $1 \%$ of the annual precipitation. The spatial variation of throughfall is high and is mainly related with morpho logical characteristics of the tree canopy, though the effect of wind could also be demonstrated. On an event basis, throughfall is mainly controlled by the amount of precipitation and to a minor degree by rainfall intensity, temperature and air humidity. Although individual holm oaks intercept a considerable amount of rainfall, the importance on the water balance of the catchment is small due to the low tree density. With a canopy cover of $8 \%$, the water loss due to interception constitutes only $4 \%$ of the annual precipitation.

RESUMEN: El papel de las encinas (Quercus rotundifolia) en la redis tribución de la precipitación se ha estudiado en las dehesas, un sistema de explotación muy extendido en el suroeste de la península Ibérica. Se han tomado medidas de la trascolación y del flujo a través del tronco en la cuenca de Guadalperalón, disponiéndose de tres años de datos a escala de eventos individuales. Se ha investigado también el efecto de la poda sobre la interceptación, realizándose aquella a intervalos de 10 años. Se seleccionaron 4 árboles, dos podados y otros dos no podados. La trascolación se midió con 163 pluviómetros distribuidos de forma regular bajo la 
cubierta de los árboles, y los datos meteorológicos se registraron cada 5 minutos. En promedio, el $26.8 \%$ de la precipitación es interceptada. Los árboles podados interceptan una cantidad de lluvia claramente menor que los no podados (23.6 y $29.9 \%$ respectivamente). El flujo por el tronco es de escasa importancia, pues representa menos del $1 \%$ de la precipitación anual. La variación espacial de la trascolación es elevada y está relacio nada con las características morfológicas de la cubierta del árbol, aunque está por demostrar el efecto del viento. A escala de evento, la trascolación está principalmente controlada por la cantidad de lluvia y, en menor medida, por su intensidad, temperatura y humedad del aire. Aunque las encinas interceptan una cantidad considerable de lluvia, su importancia en el balance hídrico de la cuenca es pequeña debido a la baja densidad de arbolado. Con una cubierta del $8 \%$, la pérdida de agua debida a inter ceptación constituye sólo el $4 \%$ de la precipitación anual.

Key words: Interception, Throughfall, Stemflow, Dehesa, Holm oaks, Pruning, Extremadura, Spain.

Palabras clave: Interceptación, Trascolación, Flujo por el tronco, Dehesa, Encina, Poda, Extremadura, España.

\section{Introduction}

Rainfall interception by vegetation has been demonstrated to constitute an important process of the hydrological cycle which can be considered as a loss in the water balance (Zinke, 1967). A variety of studies were carried out in areas with Mediterranean climate and a vegetation cover consisting of evergreen forests, composed of coniferous or holm oak species (Escarré et al., 1986; Bellot, 1988; Llorens, 1997; Domingo, 1998; Belmonte \& Romero, 1999). However very limited information is available about the role of a sparse tree cover in the distribution of surface water (Calabuig et al., 1979). The present work presents the results of an interception study carried out in a dehesa, a landuse system widespread in the southern and western part of the Iberian Peninsula, estimated to occupy more than 3 million ha (Díaz, et al., 1997). It consists of openly spaced evergreen woodland, with holm oaks and cork oaks (Quercus rotundifolia, $Q$. suber) being the dominant species. Multiple landuse characterizes this semi-natural ecosystem with extensive livestock breeding, wood production, hunting and cultivation.

The study was carried out in the Guadalperalón catchment, where surface hydrology and soil erosion is investigated since 1990 (Gómez Amelia \& Schnabel, 1992; Schnabel, 1997; Ceballos \& Schnabel, 1998; Ceballos, 1999). The main objective of the present work is to evaluate the water losses produced by rainfall interception of the sparse, savannah-like, tree cover of this mediterranean ecosystem.

Rainfall interception of holm oaks is determined through the quantification of the different water fluxes influenced by the tree cover: throughfall and stemflow. Measurements where carried out during three hydrological years, from September 1995 to August of 1998. Further specific subjects include: 
1. Evaluation of the importance of tree pruning on interception. In the dehesas trees are commonly pruned in intervals of 8 to 10 years. The reasons for pruning are manifold, such as an increase of acorn production (for fattening the Iberian black pig), the provision of additional fodder (leaves and branches) for livestock and the production of firewood.

2. The spatial distribution of throughfall below the tree canopy is determined and the possible factors producing this variation are examined.

3. The relationship between meteorological variables and throughfall is established.

4. The importance of rainfall interception in the water balance of the study catchment, and for the dehesa ecosystem, is evaluated.

5. The analytical model to estimate rainfall interception proposed by Gash (1979) with its adaptation for disperse tree cover (Gash et al., 1995) was tested using the Guadalperalón data by Mateos (2001). Only the main results are presented here.

\section{The Study Area}

The study basin is located $22 \mathrm{~km}$ northeast of the city of Cáceres in Extremadura, Spain (Figure 1). It forms part of a peneplain with slope gradients in the order of 10 to $25 \%$. The catchment with a surface area of 35.4 ha and a mean altitude of $378 \mathrm{~m}$ a.s.l. belongs to the Tajo drainage system.

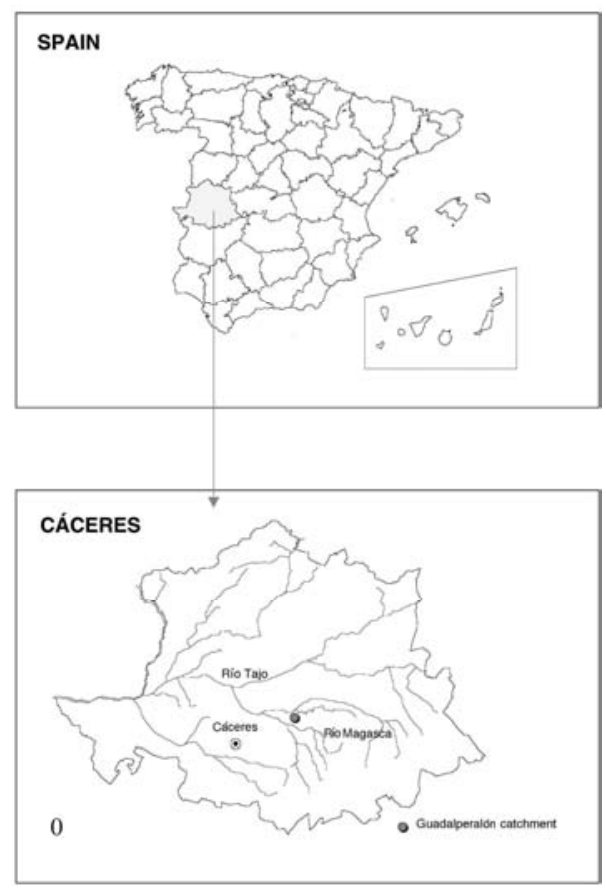

Figure 1. Location of study area 
The climate is Mediterranean, with Atlantic and continental influences, giving rise to moderate winters and hot and dry summers. Mean annual temperature is $16.1{ }^{\circ} \mathrm{C}$. Annual precipitation averages $516.2 \mathrm{~mm}$, distributed over 85 rain days (longterm meteorological data were obtained from the Observatory in Cáceres). The annual distribution shows a dry season lasting from June to September and a wet season from October to April. Annual and interannual variability of rainfall is high (Schnabel, 1998). Using the Unesco aridity index (Unesco, 1979) the climate of the area can be classified as semi-arid.

The soils in Guadalperalón are developed on precambrian schists. They are shallow $(10-30 \mathrm{~cm})$, have a silty loam structure and a low organic matter content. In the catchment, areas with a tree cover of Quercus rotundifolia alternate with areas lacking oaks. In the treeless zones, where rock outcropping is frequent, shrubs of the species Lavanduala stoechas are dominant and the herbacoues cover is very poor. At hillslopes, where trees are growing, herbaceous species dominate. Mean tree density is low with approximately 15 individuals per ha. The tree-covered hillslopes where the interception measurements were carried out have a tree density of 30 to 45 holm oaks per ha. The farm is grazed by sheep and to a minor degree by cattle and pigs.

The physical and environmental characteristics of Guadalperalón (soils, climate, topography, vegetation) are representative of widespread areas of dehesas found in the south-western part of the Iberian Peninsula.

\section{Methods}

The study was carried out using four trees, which were selected on the basis of a previous analysis of the main characteristics of the holm oaks growing in the study catchment (Mateos \& Schnabel, 1998). In order to evaluate the influence of canopy pruning on rainfall interception, two of the selected sample trees were not pruned for more than twenty years, and the other two trees were pruned in 1992, three years before the start of this study.

Rainfall interception was determined by calculating the difference between incident rainfall $(\mathrm{P})$ and the sum of throughfall $(\mathrm{Th})$ and stemflow $(\mathrm{St})$ :

$$
\mathrm{I}=\mathrm{P}-(\mathrm{Th}+\mathrm{St})
$$

Throughfall was measured using a total number of 163 simple raingauges distributed in a rectangular grid below the tree canopy. The collecting area of each device was 314 $\mathrm{cm}^{2}$. The distance between each raingauge was $1.5 \mathrm{~m}$. Incident rainfall was determined by four raingauges. One of these was a tipping bucket device of $0.2 \mathrm{~mm}$ resolution and with authomatic recording in 5 minute intervals. The others consisted of raingauges of the same design than those used for throughfall measurement.

Stemflow was monitored by collectors arranged in spiral form around the stem, using an opened rubber tube which was fixed to the stem and sealed with silicone to form a tight junction between the collector and the tree bark. The tube was connected to a 651 tank. Stemflow and throughfall was monitored on an event basis. 
Furthermore, meteorological data in Guadalperalón was registered in intervals of 5 minutes, including air temperature, relative air humidity, global solar radiation, wind velocity and wind direction. Data is downloaded by a portable computer.

During the study period (September 1995 to August 1998) 103 rainfall events were registered and the corresponding amount of stemflow and throughfall were monitored. The total amount of precipitation of these events is slightly lower than the total amount of rainfall of the three corresponding years (table 1). These differences are due to a small number of events which could not be sampled. The data of throughfall, stemflow and interception is presented in relation to the corresponding event rainfall.

Table 1. Total annual precipitation and annual event rainfall (corresponding to the throughfall and stemflow sampling) in Guadalperalón.

\begin{tabular}{|ccc|}
\hline $\begin{array}{c}\text { Hydrological } \\
\text { Year }\end{array}$ & $\begin{array}{c}\text { Total rainfall } \\
(\mathbf{m m})\end{array}$ & $\begin{array}{c}\text { Event rainfall } \\
(\mathbf{m m})\end{array}$ \\
\hline $1995-96$ & 728.0 & 708.7 \\
$1996-97$ & 692.7 & 659.7 \\
$1997-98$ & 922.8 & 896.6 \\
Mean & $\mathbf{7 8 1 . 2}$ & $\mathbf{7 5 5 . 0}$ \\
\hline
\end{tabular}

\section{Results and Discussion}

\subsection{Precipitation}

Mean annual rainfall of the three years of investigation was $781.2 \mathrm{~mm}$ (table 1), exceeding strongly the long-term mean based on a series of data of 91 years from the meteorological station of Cáceres $(516.2 \mathrm{~mm})$. The data of this station can be used as a reference for interpreting the data obtained in the study basin due to its proximity and similar altitude (Schnabel, 1997).

The three hydrological years can be classified as very humid (INM, 1994), especially the last one (1997-98), which registered $922.8 \mathrm{~mm}$, an amount which was only exceeded twice at the beginning of the century. Exceptional precipitation was observed during November of 1997, with a total of $355.4 \mathrm{~mm}$, the maximum monthly rainfall of the 91 year record. Large part of this amount was produced during the $5^{\text {th }}$ and $6^{\text {th }}$ of November due to a rainstorm event registering a 24 hour maximum of $135.4 \mathrm{~mm}$. January of 1996 was also exceptionally humid with $246.4 \mathrm{~mm}$ of rain. Figure 2 represents monthly rainfall for each of the study years, illustrating that most precipitation was registered from November to January, with December receiving more than $120 \mathrm{~mm}$ in each of the years. Most of the months of October, February, March and April, however, registered below average amounts. This contrasts with the month of May, during which in all three cases rainfall exceeded the long-term mean. 


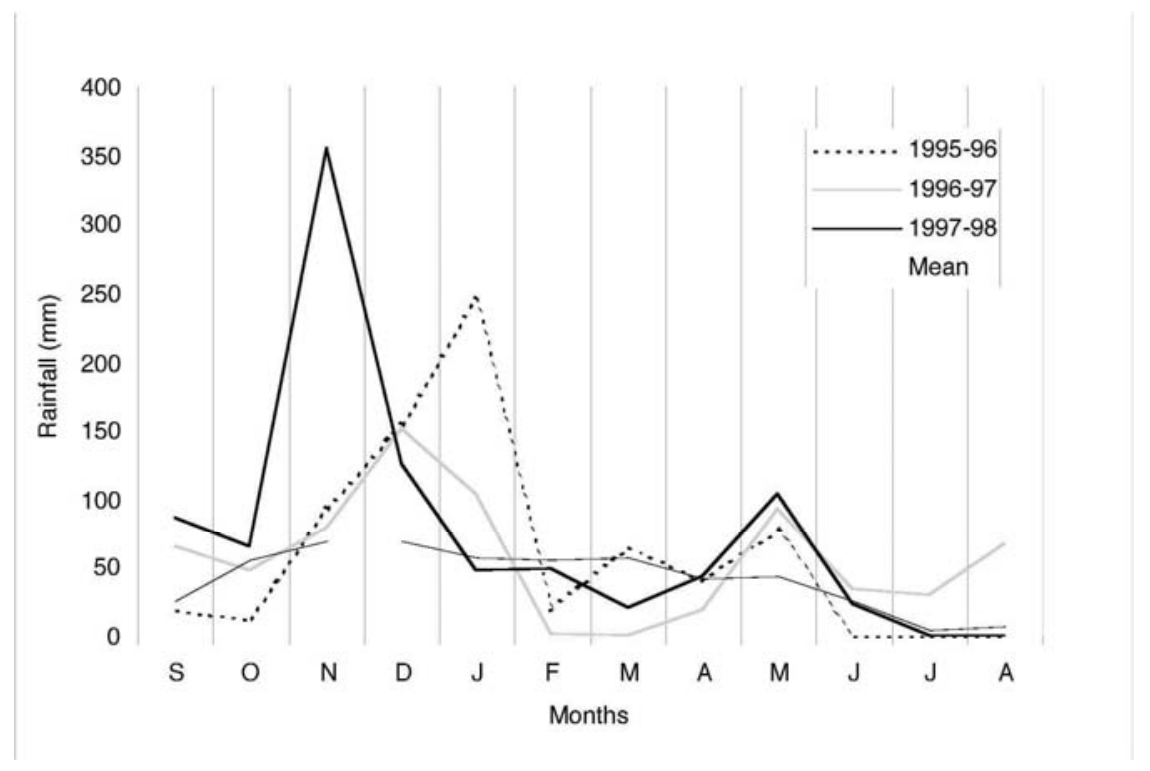

Figure 2. Monthly precipitation during the three years of investigation at Guadalperalon and average amounts from the meteorological station in Cáceres.

During the study period a total of 103 events were sampled. The frequency distribution of the event rainfall, represented in figure 3, shows two dominant groups: events with an amount of 5 to $10 \mathrm{~mm}(24.3 \%)$ and those with an amount of 10 to $20 \mathrm{~mm}$ (23.3\%). Rainfall of less than $10 \mathrm{~mm}$ represents $36.9 \%$ of the total number of events. In contrast, the least frequent rainstorms were those with 40 to $50 \mathrm{~mm}$ of precipitation (1.9\%) followed by those of 30 to $40 \mathrm{~mm}(8.7 \%)$. However, rainstorms which registered amounts in excess of $50 \mathrm{~mm}$ were quite frequent (10.7\%).

With respect to rainfall intensity, most of the events were characterized by low intensities: $51.5 \%$ registered maximum 10-minute intensities (I-10) below $10 \mathrm{~mm} \mathrm{~h}^{-1}$. However, moderate $\left(20-40 \mathrm{~mm} \mathrm{~h}^{-1}\right)$ and high intensity storms $\left(>40 \mathrm{~mm} \mathrm{~h}^{-1}\right)$ represented a fairly large number of the events, with $14.5 \%$ and $10.7 \%$, respectively. The third study year (1997-98) registered the largest number of high intensity storms. Since the start of the investigation in Guadalperalón in 1990 six events were observed with I-10 either in excess of $60 \mathrm{~mm} \mathrm{~h}^{-1}$ or with a daily maximum amount greater than $55 \mathrm{~mm}$ (Schnabel, 1999). Four of these events were observed during the period of the interception study.

\subsection{Throughfall}

Throughfall for each sample tree was calculated as the average height of water collected in the raingauges situated below the tree canopy. On average $550,1 \mathrm{~mm}$ of throughfall were registered, which represents almost $73 \%$ of the total precipitation 


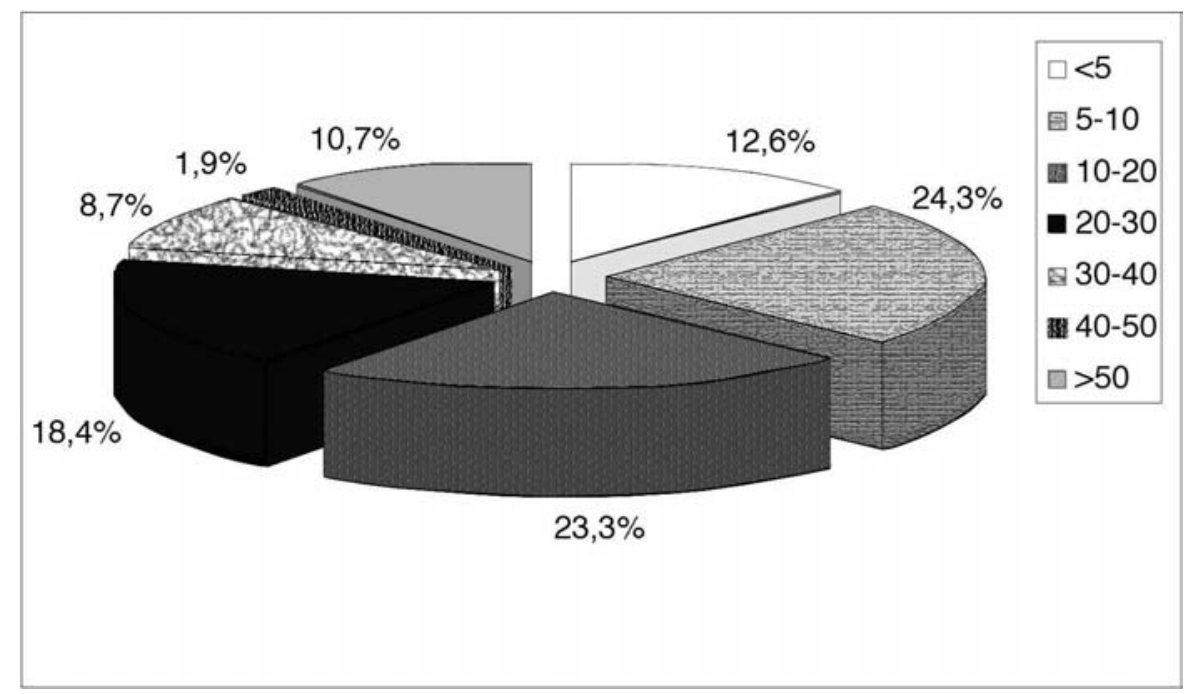

Figure 3. Frequency distribution of the event rainfall amounts (1995-1998).

(table 1). Throughfall varied between $491.5 \mathrm{~mm}$ and $654.8 \mathrm{~mm}$, though as a percentage of rainfall, it varied only between 71.1 and $74.5 \%$ (table 2).

On average throughfall of the pruned and unpruned trees was 75.9 and $69.9 \%$, respectively, which represents a difference of $6 \%$ with respect to the annual rainfall (table 2). This can be explained by the lower density of the canopy and a lower amount of biomass of the pruned trees. The volume and distribution of throughfall depends, amongst other factors, on the storage capacity of the tree canopy, which is determined by its morphology (amount of biomass, structure and angle of the branches), the characteristics of the rainfall event (amount, intensity, duration), as well as the prevailing atmospheric conditions. In order to determine the role of the meteorological factors in controlling throughfall, factor analysis was carried out (see for more detail Mateos, 2001). It was considered that the morphological characteristics of the tree canopy did not change during the study period. The analysis, based on the event scale, was carried out using the average values of throughfall of the four trees. Further variables considered are: total amount of rainfall,

Table 2. The annual amount of throughfall as a percentage of incident rainfall of each of the sampling trees $(A 1-A 4)$ and mean values.

\begin{tabular}{|ccccccc|}
\hline $\begin{array}{c}\text { Hydrological } \\
\text { Year }\end{array}$ & $\begin{array}{c}\text { Rainfall } \\
(\mathbf{m m})\end{array}$ & $\begin{array}{c}\text { A1 } \\
(\mathbf{\%})\end{array}$ & $\begin{array}{c}\text { A2 } \\
(\boldsymbol{\%})\end{array}$ & $\begin{array}{c}\text { A3 } \\
(\mathbf{\%})\end{array}$ & $\begin{array}{c}\text { A4 } \\
(\mathbf{\%})\end{array}$ & $\begin{array}{c}\text { Mean } \\
(\boldsymbol{\%})\end{array}$ \\
\hline $1995-96$ & 708.7 & 75.8 & 74.6 & 69.4 & 64.7 & 71.1 \\
$1996-97$ & 659.7 & 78.6 & 77.4 & 74.1 & 68.0 & 74.5 \\
$1997-98$ & 896.6 & 74.8 & 73.9 & 73.8 & 69.6 & 73.0 \\
Mean & $\mathbf{7 5 5 . 0}$ & $\mathbf{7 6 . 4}$ & $\mathbf{7 5 . 3}$ & $\mathbf{7 2 . 4}$ & $\mathbf{6 7 . 4}$ & $\mathbf{7 2 . 9}$ \\
\hline
\end{tabular}


maximum 10-minute rainfall intensity, duration of precipitation, mean air temperature, relative air humidity, solar radiation, wind velocity. The results of the factor analysis show that the rainfall characteristics (amount, intensity, duration) are the dominant group of factors, representing the highest weight for explaining the amount of throughfall, with high positive correlations $(r=0.99 ; r=0.90 \mathrm{y} r=0.83$, respectively). The importance of the amtmospheric conditions could also be demonstrated (humidity, temperature, global radiation), though the influence of wind velocity could not be proven. The influence of the latter factors on throughfall can be explained by the role they play in the evaporation process. Increased evaporation of intercepted water increases further interception and hence reduces throughfall.

The spatial variation of throughfall, whose importance was described by several authors (Eschner, 1967; Ford and Deans, 1978; Durocher, 1990; Belmonte y Romero, 1999), was also investigated in this research. In order to determine the distribution of throughfall at the soil surface isoline maps were produced, based on linear krigging. This was done for each of the trees using mean throughfall of each collector. Throughfall below the tree canopy was highly variable. However, similar patterns could be observed. Distribution was concentric around the stem, with lowest values close to the stem, and increased throughfall with increasing distance to the stem. Highest values, occasionally higher than incident rainfall, were registered below the end of main branches, which seem to canalize part of the intercepted water. Large amounts of throughfall were also registered below the border of the canopy, at the site exposed to the main wind direction (southeast to southwest).

\subsection{Stemflow}

Stemflow is expressed in millimeters, which is calculated in relation to the surface area of the canopy of the sample trees. The average amount of annual stemflow represents only $0.3 \%$ of total rainfall (table 3). No significant differences were observed between the pruned and un-pruned trees, and neither between different years. These low values of stemflow can be attributed to the morphological characteristics of the holm oaks, i.e. the rugosity of the bark, and its effect as a sponge. Probably the horizontal alignment of the main branches also influences, favouring either drainage by dripping of water from the branches or retention of water, and hence reduces the flow towards the

Table 3. Annual incident rainfall and interception, as well as throughfall, interception and stemflow expressed as a percentage of rainfall, during the study period from 1995 until 1998.

\begin{tabular}{|cccccc|}
\hline $\begin{array}{c}\text { Hydrological } \\
\text { Year }\end{array}$ & $\begin{array}{c}\text { Rainfall } \\
(\mathbf{m m})\end{array}$ & $\begin{array}{c}\text { Throughfall } \\
(\mathbf{\%})\end{array}$ & $\begin{array}{c}\text { Stemflow } \\
(\mathbf{\%})\end{array}$ & $\begin{array}{c}\text { Interception } \\
(\mathbf{\%})\end{array}$ & $\begin{array}{c}\text { Interception } \\
(\mathbf{m m})\end{array}$ \\
\hline $1995-96$ & 708.7 & 71.12 & 0.33 & 28.55 & 202.3 \\
$1996-97$ & 659.7 & 74.50 & 0.33 & 25.17 & 166.0 \\
$1997-98$ & 896.6 & 73.03 & 0.25 & 26.72 & 239.6 \\
Mean & $\mathbf{7 5 5 . 0}$ & $\mathbf{7 2 . 8 8}$ & $\mathbf{0 . 3 0}$ & $\mathbf{2 6 . 8 1}$ & $\mathbf{2 0 2 . 4}$ \\
\hline
\end{tabular}




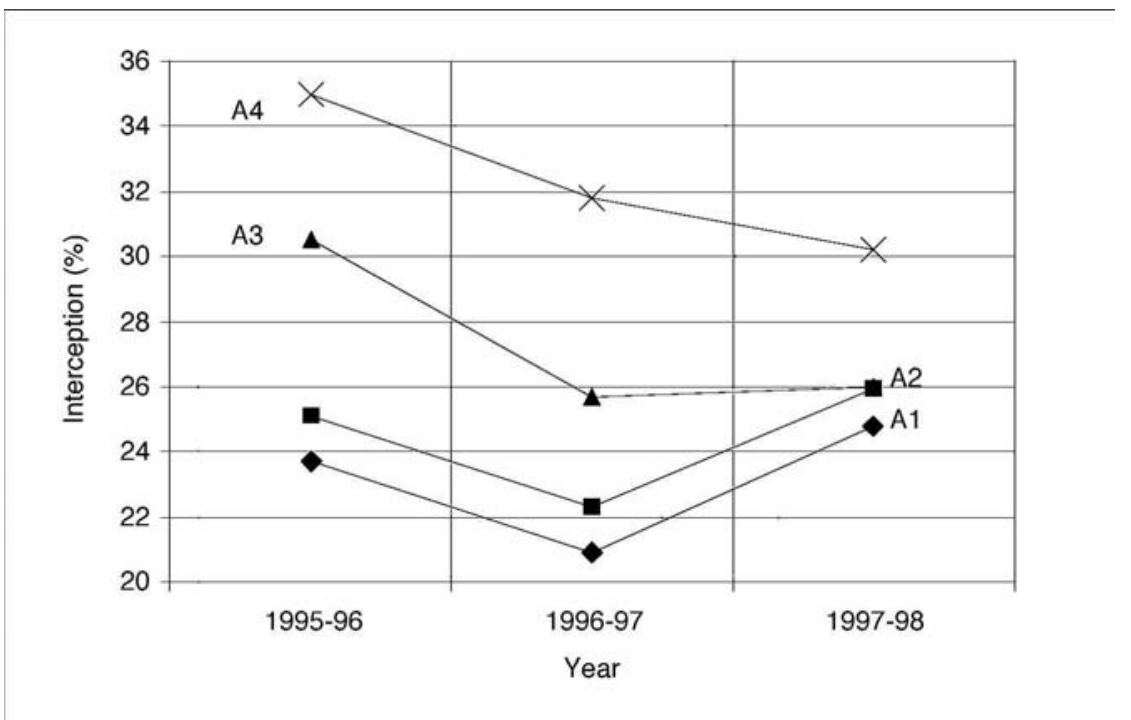

Figure 4. Development of rainfall interception for each of the sample trees between the hydrological years 1995-96 and 1997-98.

stem. The low value of stemflow indicates that its influence on the hydrological balance of the catchment is very small.

\subsection{Interception}

The average annual water loss produced by interception for the study period amounted to $202.4 \mathrm{~mm}$, which represents $26.8 \%$ of the total rainfall. The annual amounts of throughfall as an average of the four sample trees varied between $166.0 \mathrm{~mm}$ and 239.6 $\mathrm{mm}$, though interception expressed as a percentage of rainfall varied only between $25.2 \%$ and $28.6 \%$ (table 3 ).

Mean annual interception of the pruned and unpruned trees was $23.6 \%$ and $29.9 \%$, respectively, representing a difference of approximately $6 \%$. However, the annual values for the individual trees varied throughout the study period (Figure 4). Interception of the unpruned trees was highest during the first year and was lower during the second and the third year. This variation can be explained by the characteristics of the rainfall events, with higher interception related with lower amounts and/or lower intensities of precipitation. The first year registered a smaller number of intensive rainstorms. Interception of the pruned trees showed a contrasting behaviour. Although the second year produced less throughfall than the first one, the difference is less pronounced than in the case of the unpruned holm oaks. The values of the third year are even higher than the first one (Figure 4). As a result, the difference of interception between the two groups was $8.7 \%$ during $1995-96$ and only $2.7 \%$ in 1997-98. This decreasing difference is probably related with a 
change of the canopy of the pruned trees. It is assumed that the biomass of these trees increased during the three year period. Although extrapolation of this data is limited due to the reduced number of sample trees and sample years, it may be argued that 6 years after having practiced pruning (carried out during 1992 in our case) its effect on throughfall is rather small.

Water loss through interception by holm oaks represents a fairly high percentage of annual rainfall (26.8\%), which are of importance especially in the Mediterranean areas, with its semi-arid climate conditions and highly variable rainfall. However, this value is based on the individual tree, neglecting the open spaces. In the Guadalperalón catchment with a mean tree density of 15 individuals per hectare and a canopy cover of $8 \%$, water loss produced by interception is estimated to be only $4 \%$. Tree density of dehesas varies strongly in Spain and Portugal. In order to obtain some idea about the interception losses produced by holm oaks in a drainage basin a simple estimation was carried out. Assuming an average canopy cover of $45.1 \mathrm{~m}^{2}$ for each tree (equivalent to the mean value of the sample trees used in this study) and taking into account the amount of interception recorded in the sample grid with an average size of $99 \mathrm{~m}^{2}$, the water loss by interception is estimated to be approximately $5 \%$ with a tree density of 20 individuals/ha and $13 \%$ with a density of 50 trees/ha. These values can only be considered as very crude estimates.

The analytical model of Gash for disperse tree cover (Gash et al., 1995), which is based on morphological and climatological parameters, was tested with the data obtained in Guadalperalón. The result was not satisfactory because the predicted values presented less than $50 \%$ of the observed values of interception (Mateos, 2001).

\section{Conclusions}

The sampled holm oaks in Guadalperalón intercepted important amounts of rainfall, with approximately $27 \%$. However, due to their disperse cover water loss produced by interception in Guadalperalón was estimated to be only $4 \%$ with an average tree density of 15 individuals per hectare. Tree density in the wooded pasturelands of the southwestern part of the Iberian Peninsula varies strongly, and as a consequence, interception losses will vary too.

Of the different flows related with interception, throughfall is of major importance, accounting for $73 \%$ of the incident rainfall, whereas stemflow represents only $0.3 \%$.

Spatial variation of throughfall at the ground surface is high, and is primarily related with the morphological characteristics of the tree and to a minor degree with wind direction. Throughfall is lowest in the area around the tree stem, where values represent less than $50 \%$ of total rainfall. Maximum values, even higher than incident rainfall, where recorded below the main branches and at the border of the canopy cover.

On an event basis, throughfall is mainly controlled by the amount of precipitation and to a minor degree by rainfall intensity, temperature and air humidity. The latter two factors indicate the importance of evaporation in the interception process. 
Pruning of the canopy of holm oaks reduced interception by approximately $6 \%$ with respect to annual rainfall during the three years of observation and covering a period of 3 to 6 years after pruning was carried out.

\section{Acknowledgments}

This investigation was carried out within the framework of a research project financed by the Spanish Ministry of Science and Technology (HID98-1056-C02-02). Funding was also supplied by the Spanish Soil Erosion Network (RESEL, Ministerio de Medio Ambiente) and a scholarship was provided by the Regional Government of Extremadura.

\section{Bibliografía}

Bellot, J. (1989). Análisis de los flujos de deposición global, trascolación, escorrentía cortical y deposición seca en el encinar mediterráneo de l'Avic (Sierra de Prades), Tarragona. Unpublished PhD Thesis, Universidad de Alicante.

Belmonte, F. \& Romero, M. A. (1999). Interceptación en algunas especies de matorral mediterráneo. Cuadernos de Ecología y Medioambiente, Universidad de Murcia.

Bernet, R. (1995). La cubierta herbácea en sistemas de dehesa degradados. Junta de Extremadura y FUNDICOT, Cáceres.

Calabuig, E. L.; Gago Gamallo, Ma . L. \& Gómez Gutiérrez, J. M. (1979). Influencia de la encina (Quercus rotundifolia Lam.) en la distribución del agua de lluvia. Anuario del Centro de Edafología y Biología Aplicadas, 4: 143-159.

Ceballos, A. (1999). Procesos hidrológicos en una pequeña cuenca hidrográfica bajo explotación de dehesa en Extremadura. Universidad de Extremadura y Caja Duero, Cáceres, 196 pp.

Ceballos, A. \& Schnabel, S. (1998). Hydrological behaviour of a small catchment in the dehesa landuse system (Extremadura, SW Spain). Journal of Hydrology, 210, 146160.

Díaz, M., Campos, P. \& Pulido, F.J. (1997). The Spanish dehesas: a diversity in land-use and wildlife. In: J. Pain \& M.W. Pienkowsky (eds.), Farming and Birds in Europe, Academic Press, San Diego, 178-209.

Durocher, M. G. (1990). Monitoring spatial variability of forest interception. Hydrological Processes, vol. 4, 215-229.

Escarré, A., Lledó, M. J., Bellot, J., Martín, J., Escaplés, A., Seva, E., Rovira, A. \& Sánchez, J. R. (1986). Balance hídrico, meteorización y erosión en una pequeña cuenca de encinar mediterráneo (Proyecto LUCDEME). Monografía, 47. ICONA, Madrid.

Eschner, A.R. (1967). Interceptation and soil moisture distribution. In: Sopper, W.E. \& Lull, H.W. (eds.): Forest Hydrology, Pergamon Press, Oxford, 191-200.

Ford, E.D. \& Deans, J.D. (1978). The effects of canopy structure on stemflow, throughfall and interception loss in a young stik spruce plantation. Journal of Applied Ecology, 15, 905-917. 
Gash, J.H.C., (1979). An analytical model of rainfall interception by forests. Quar. J. Royal Meteorology Society, 105 (443), 43-55.

Gash, J.H.C., Lloyd, C.R. \& Lauchaud, G. (1995). Estimating sparse forest rainfall interception with an analytical model. Journal of Hydrology, 170, 79-86.

Gómez Amelia, D. \& Schnabel, S. (1992). Procesos sedimentológicos e hidrológicos en una pequeña cuenca bajo explotación de dehesa en Extremadura. In: López Bermúdez, F., Conesa García, C. \& Romero Díaz, M.A. (eds.): II Reunión Nacional de Geomorfología. S.E.G., Murcia, 55-63.

INM (Instituto Nacional de Meteorología) (1994). Calendario Meteorológico, 1993. Madrid.

Llorens, P., Poch, R., Latron, J. \& Gallart, F. (1997). Rainfall interception by Pinus sylvestris forest patch overgrown in a Mediterranean mountainous abandoned area. I. Monitoring design and results down to the event scale. Journal of Hydrology, 199, 331-345.

Llorens, P. (1997). Rainfall interception by Pinus sylvestris forest patch overgrown in a Mediterranean mountainous abandoned area. II. Assessment of the applicability of Gash's analytical model. Journal of Hydrology, 199, 346-359.

Mateos Rodríguez, A. B. \& Schnabel, S. (1998). Medición de la interceptación de las precipitaciones por la encina (Quercus rotundifolia Lam.): Metodología e instrumentalización. Rev. Norba, 10. UEX, Cáceres, 95-112.

Mateos, A. B. (2001). Interceptación de las precipitaciones por la encina Quercus rotun difolia lam. en espacios adehesados: Cuenca experimental de Guadalperalón. Tesis Doctoral. Dpto. de Geografía, Facultad de Filosofía y Letras, UEX, Cáceres, 197 pp.

Schnabel, S. (1997). Soil erosion and runoff production in a small watershed under silvopastoral landuse (dehesas) in Extremadura, Spain. Geoforma Ediciones, Logroño.

Schnabel, S., Gómez Amelia, D. \& Ceballos Barbancho, A. (1999). Extreme events and gully erosion. Proceedings of the International Seminar on Land Degradation and Desertification, International Geographical Union, Lisbon 1998, 17-26.

UNESCO (1979): Carte de la répartition mondiale des régions arides. Not. Tech. MAB 7, Paris.

Zinke, P. (1967): Forest interception studies in the United States. In: Sopper, W.E. \& Lull, H.W. (eds.): Forest Hydrology, Pergamon Press, Oxford, 137-161. 